Artikel

\title{
ANALISIS PENERAPAN MODEL KONTEKSTUAL DALAM PEMBELAJARAN MENULIS TEKS DESKRIPSI SISWA KELAS VII SMP NEGERI 1 LABUHAN DELI TAHUN PEMBELAJARAN 2017/2018
}

\section{Oleh}

\section{Marta Diana Br PA}

NIM 2131111033

\section{Dosen Pembimbing Skripsi}

Dr. Mutsyuhito Solin, M.Pd.

Telah Diverifikasi dan Dinyatakan Memenuhi

Syarat untuk Diunggah pada Jurnal Online

Medan, November 2017

Menyetujui :

Editor,

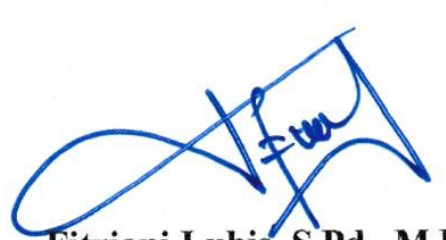

Fitriani Lubis, S.Pd., M.Pd. NIP 197708312008122001

Dosen Pembimbing Skripsi,

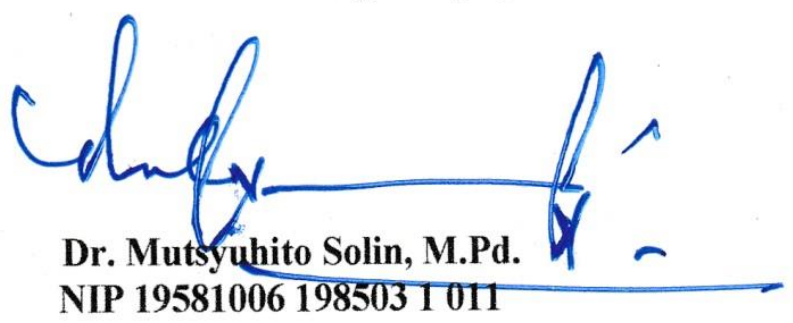




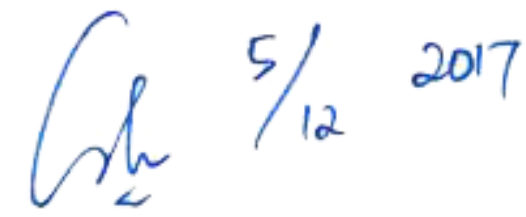

\title{
ANALISIS PENERAPAN MODEL KONTEKSTUAL DALAM PEMBELAJARAN \\ MENULIS TEKS DESKRIPSI SISWA KELAS VII SMP NEGERI 1 \\ LABUHAN DELI TAHUN PEMBELAJARAN 2017/2018
}

\author{
oleh \\ Marta Diana Br Pa (martadianabrpa@gmail.com) \\ Dr. Mutsyuhito Solin, M.Pd.
}

Penelitian ini bertujuan untuk mengetahui penerapan langkahlangkah konstruktivisme, inquiri, questioning, learning community, modeling, reflection, dan authentic assessment dalam pembelajaran menulis teks deskripsi siswa SMP Negeri 1 Labuhan Deli Tahun Pembelajaran 2017/2018 dan untuk mengetahui kemampuan menulis teks deskripsi siswa SMP Negeri 1 Labuhan Deli dengan menggunakan model kontekstual. Sumber data dalama penelitian ini adalah rekaman dokumentasi penerapan kontekstual yang dilakukan oleh guru dalam pembelajaran menulis teks deskripsi siswa kelas VII SMP Negeri 1 Labuhan Deli. Metode yang digunakan dalam penelitian ini adalah metode deskriptif kualitatif. Instrument yang digunakan adalah peneliti sendiri (human instrument). Analisis data yang dilakukan peneliti dengan cara menganalisis penerapan langkah-langkah yang terdapat didalam model kontekstual yang telah diterapkan oleh guru dalam pembelajaran menulis teks deskripsi siswa. Hasil analisis peneliti menunjukkan bahwa guru melakukan enam belas langkah dari tujuh belas langkah yang terapat dalam model kontekstual dengan nilai presentasi $94 \%$ dan nilai siwa dalam menulis teks deskripsi berdasarkan struktur dan ciri kebahasaan mencapai 79,93 yang tergolong kedalam katagori baik.

Kata Kunci: Analisis, kontekstual, deskripsi.

\section{PENDAHULUAN}

Pelajaran Bahasa Indonesia mencakup kemampuan berbahasa yang meliputi empat aspek yakni menyimak, berbicara, membaca, dan menulis. Keempat aspek tersebut merupakan pencapaian yang saling berhubungan Siregar ( 2014: 1 ). 
Ditinjau dari sisi pelaku kegiatan berbahasa menulis dan berbicara merupakan jenis kegiatan berbahasa yang aktif. Hal ini dikarenakan penulis dan pembicara harus aktif mengekspresikan pemikiran/gagasan dan ide-ide yang terdapat di dalam pikiran ke dalam bentuk tulisan sehingga dapat dipahami oleh pembaca. Menulis merupakan kegiatan yang aktif dan kreatif karena kegiatan yang dihasilkan melalui tulisan itu adalah pencerminan ide, gagasan pikiran seseorang yang dapat dipahami atau dimengerti oleh orang lain yang disampaikan melalui tulisan. Salah satu keterampilan menulis adalah menulis teks deskripsi.

Teks merupankan suatu bahasa yang digunakan sebagai ungkapan suatu kegiatan sosial baik secara lisan maupun tulisan dengan struktur berpikir yang lengkap. Menurut Halliday dalam Mahsun ( 2013:1 ) menyatakan teks merupakan jalan menuju pemahaman tentang bahasa. Menurutnya teks merupakan bahasa yang berfungsi atau bahasa yang sedang melaksanakan tugas tertentu dalam konteks situasi. Teks deskripsi adalah sebuah paragraf dimana gagasan utamanya disampaikan dengan cara menggambarkan secara jelas objek, tempat, atau peristiwa yang sedang menjadi topik kepada pembaca. Sehingga pembaca seolah-olah merasakan langsung apa yang sedang diungkapkan dalam teks tersebut.

Semi dalam Ferlin ( $2011: 2$ ) berpendapat deskripsi adalah tulisan yang tujuannya memberikan perincian atau detail tentang obyek sehingga dapat memberi pengaruh pada sensitivitas dan imajinasi pembaca atau pendengar, bagaikan mereka ikut melihat, mendengar, merasakan atau mengalami langsung obyek tersebut. Menurut Mahsun ( 2013 : 28 ) menyatakan teks tipe ini memiki tujuan sosial untuk menggambarkan ciri fisiknya. Gambarkan yang dipaparkan dalam teks ini haruslah yang spesifik menjadi ciri keberadaan objek yang digambarkan. Oleh karena itu, teks deskripsi memiliki struktur berpikir: pernyataan umum, uraian bagian-bagian. Sebagai sebuah teks, maka semua struktur yang membentuk teks diikat oleh benang pengikat yang berupa pengulangan, misalnya pengulangan utuh.

Proses belajar-mengajar harus mengetahui apa saja kendala-kendala yang dihadapi pada saat menerapkan model pembelajaran tersebut, yang dapat diketahui 
melalui proses penelitian, sehingga penelitian ini perlu dilakukan. Dengan demikian, para pengajar sangat penting untuk mempelajari dan memperluas wawasan tentang model pembelajaran yang telah diketahui. Karena dengan menguasai beberapa model pembelajaran, seorang guru akan merasakan adanya kemudahan di dalam pelaksanaan pembelajaran di kelas sehingga tujuan pembelajaran yang hendak dicapai dalam proses pembelajaran dapat tercapai dengan tuntas sesuai dengan yang diharapkan oleh sekolah. Heriasa ( 2014 : 3 ) menyatakan bahwa model kontekstual salah satu pendekatan yang dapat memberikan kesempatan kepada siswa untuk mengalami secara langsung dan terlibat secara penuh dalam proses pembelajaran serta menghubungkan materi yang dipelajari dengan situasi kehidupan nyata. Model pembelajaran kontekstual yaitu suatu pembelajaran yang menekankan kepada proses keterlibatan siswa secara penuh untuk dapat menemukan materi yang dipelajari dan menghubungkannya dengan situasi kehidupan nyata sehingga mendorong siswa untuk dapat menerapkannya dalam kehidupan mereka. Pembelajaran kontekstual merupakan suatu konsepsi dari pembelajaran yang membantu pembelajar/guru menghubungkan isi mata pelajaran dengan situasi yang sebenarnya dan motivasi peserta didik untuk membuat hubunga-hubungan pengetahuan dengan penerapan di dalam kehidupan mereka sebagai anggota keluarga, warga Negara dan pekerja serta mengaikannya di dalam kerja keras yang diperlukan dalam belajar Yamin (2013 : 52).

Model pembelajaran kontekstual dipandang sangat menyentuh siswa dengan dunia nyata yang ada di sekitarnya. Dalam pendekatan kontekstual siswa diberikan kesempatan mengekspresikan pikiran dan mengungkapkan idenya dalam bentuk tulisan sesuai dengan kehidupan nyata siswa. Model pembelajaran ini juga dapat dipandang sebagai suatu proses pendidikan yang holistik dan bertujuan memotivasi siswa untuk memahami makna materi pelajaran yang dipelajarinya dengan mengaitkan materi tersebut dengan konteks kehidupan mereka sehari-hari (konteks pribadi, sosial, dan kultural) sehingga siswa memiliki pengetahuan, keterampilan yang secara fleksibel dapat diterapkan (ditransfer) dari satu permasalahan dan konteks ke permasalahan. 
Model pembelajaran kontekstual sangat cocok digunakan dalam pembelajaran menulis, karena pembelajaran menulis membutuhkan wawasan yang luas, kreativitas, dan keaktifan yang dapat membantu siswa untuk menemukan ide-ide baru dengan mandiri yang akan dituangkan ke dalam bentuk tulisan. Model pembelajaran ini, cara berpikir siswa akan lebih terbuka untuk menemukan ide-ide mereka melalui kehidupan nyata. Siswa akan diberikan kesempatan untuk menemukan dan mengonstruksikan sendiri pengetahuan yang mereka dapat untuk dihubungkan dengan dunia nyata sehingga apa yang mereka pelajari dapat dipahami dengan baik.

Guru sebagai pengajar dan pendidik harus pintar-pintar memilih strategi, model, dan teknik pembelajaran yang tepat untuk mengantarkan materi pelajaran kepada peserta didik. Jadi, guru tidak cukup hanya datang ke sekolah, mengajar, dan pulang guru Perlu lebih memikirkan lagi, bagaimana cara siswa bisa belajar dan memahami materi yang diajarkan dengan baik. Oleh sebab itu, peneliti akan melakukan penelitian tentang penerapan model kontekstual dalam pembelajaran menulis teks deskripsi pada siswa kelas VII SMPN 1 Labuhan Deli. Yang ditekankan di dalam penelitian ini adalah proses penerapan model kontekstual dalam pembelajaran menulis teks deskripsi yang dilakukan guru dalam proses belajar mengajar di sekolah, sudah sesuai dengan langkah-langkah yang terdapat di dalam model kontekstual atau belum.

\section{METODE PENELITIAN}

Penelitian ini dilakukan untuk dapat menggambarkan bagaimana penerapan model pembelajaran kontekstual dalam pembelajaran menulis teks deskripsi siswa kelas VII SMP Negeri 1 Labuhan Deli. Penelitian ini menggunakan metode deskriptif kualitatif. Metode penelitian kualitatif merupakan jenis penelitian yang tidak mengandalkan bukti berdasarkan logika matematis, prinsip angka atau metode statisti. Rahayu ( 2013 : 5 ) metode deskripsi kualitatif yaitu mendeskripsikan subjek dan objek apa adanya, kemudian data yang diperoleh diolah dengan gaya pemaparan yang menggunakan bahasa verbal. Penelitian kualitatif adalah penelitian yang cara 
pengamatan dan pengumpulan data dilakukan dalam latar alamiah, artinya tanpa ada manipulasi subjek yang akan diteliti. Penelitian ini dilakukan untuk melaporkan keadaan objek yang diteliti sesuai dengan apa adanya. Teknik pengumpulan data yang digunakan dalam penelitian ini yaitu teknik observasi partisipasi pasif (passive participation), dan dokumentasi. Menurut sugiyono ( 2012 : 312 ) observasi partisipasi pasif (passive participation) yaitu peneliti datang di tempat kegiatan orang yang diamati, tetapi tidak dalam kegiatan tersebut. Teknik ini dipilih berdasarkan pertimbangan bahwa teknik dokumentasi dianggap paling sesuai dengan sifat objek penelitian yang berupa penerapan model kontekstual yang dilakukan guru dalam pembelajaran menulis teks deskripsi siswa di dalam kelas.

\section{HASIL PENELITIAN DAN PEMBAHASAAN}

\section{Hasil Penelitian Penerapan Langkah-Langkah Model Kontekstual dalam} Pembelajaran Menulis Teks Deskripsi Siswa

Hasil penelitian penerapan langkah-langkah model kontekstual dalam pembelajaran menulis teks deskripsi siswa (a) Penerapan langkah kontruktivisme sudah dilakukan guru dengan baik. Hal ini dapat dilihat dari kegiatan guru di dalam kelas yang sudah melakukan langkah kontuktivisme berdasarkan indikator yang sudah sudah divalidasi.

Guru menjelaskan tujuan pembelajaran diawal pembelajaran sebelum memasuki materi pembelajaran yang akan dipelajari. Setelah guru menjelaskan tujuan pembelajaran, guru membimbing siswa untuk bekerja serta menemukan sendiri pengetahuan tentang pembelajaran teks deskripsi melalui buku siswa, selanjutnya guru membimbing siswa untuk mengembangkan pemikiran, melakukan kegiatan belajar bermakna dan berkesan serta mengkontruksikan pengetahuan dan keterampilan yang baru ditemukan siswa tentang teks deskripsi. (b) Penerapan langkah menemukan (inquiri) sudah dilakukan guru dengan baik. Hal ini dapat dilihat dari kegiatan guru di dalam kelas yang sudah melakukan langkah menemukan (inquiri) berdasarkan indikator yang sudah divalidasi. 
Dilangkah menemukan (inquiri) guru menugaskan siswa untuk mengamati gambar pemandangan pantai cermin yang telah dibagikan oleh guru untuk menemukan dan mengumpulkan data. Setelah siswa menemukan data, siswa dibimbing oleh guru untuk melakukan proses pemindahan pengamatan menjadi pemahaman tentang gambar pantai padang cermin yang telah diamati oleh siswa. (c) Penerapan langkah Bertanya (questioning) sudah dilakukan guru dengan baik. Hal ini dapat dilihat dari kegiatan guru di dalam kelas yang sudah melakukan langkah Bertanya (questioning) berdasarkan indikator yang sudah divalidasi.

Di dalam langkah ini guru bertanya kepada siswa untuk mengetahui seberapa besar pemahaman siswa tentang teks deskripsi yang sedang dipelajari, setelah mengetahui seberapa besar pemahaman siswa tentang teks deskrips, guru memberikan rangsangan atau motivasi kepada siswa untuk meningkatkan rasa ingin tahu siswa tentang teks deskripsi yang sedang dipelajari oleh siswa. (d) Penerapan langkah komunitas belajar (learning community) sudah dilakukan guru dengan baik. Hal ini dapat dilihat dari kegiatan guru di dalam kelas yang sudah melakukan langkah komunitas belajar (lerning community) berdasarkan indikator yang sudah divalidasi.

Di dalam langkah kominitas belajar (learning community) guru membagi siswa menjadi 6 kelompok, setelah guru membagikan siswa kedalam kelompok, guru menugaskan siswa untuk berdiskusi tentang objek yang terdapat di dalam gambar yang telah diamati oleh siswa dan guru menugaskan siswa untuk melakukan kegitan bekerja sama. (e) Penerapan langkah pemodelan (modeling) sudah dilakukan guru dengan baik. Hal ini dapat dilihat dari kegiatan guru di dalam kelas yang sudah melakukan langkah pemodelan (modeling) berdasarkan indikator yang sudah divalidasi. Dilangkah pemodelan ini guru memberikan suatu contoh kepada siswa cara membuat teks deskripsi berdasarkan melihat objek yang ada di gambar yang telah dibagikan oleh guru. (f) Penerapan langkah refleksi (reflection) yang dilakukan oleh guru belum terlaksana dengan baik. Hal ini dapat dilihat dari kegiatan guru di dalam kelas yang tidak melakukan langkah refleksi (reflection) dengan sempurna berdasarkan indikator yang sudah divalidasikan. Dalam langkah ini seharusnya guru 
menugaskan siswa untuk melakukan kegiatan presentasi dan melakukan kegiatan menulis ringkasan secara mandiri pengetahuan yang siswa dapatkan tentang teks deskripsi. (g) Penerapan langkah penilaian yang sebenarnya (authentic assessment) sudah dilakukan guru dengan baik. Hal ini dapat dilihat dari kegiatan guru di dalam kelas yang sudah melakukan langkah penilaian yang sebenarnya (authentic assessment)berdasarkan indikator yang sudah divalidasi. Di dalam langkah ini guru terlihat melakukan kegiatan penilai secara langsung keterampilan presentasi siswa di depan kelas dan melakukan penilaian terhadap tugas-tugas siswa yaitu hasil tulisan siswa tentang teks deskripsi berdasarkan struktur dan ciri kebahasaan.

\section{Hasil Penelitian Kemampuan Menulis Teks Deskripsi Siswa}

Setelah tes dilaksanakan maka tahap selanjutnya adalah melakukan penghitungan nilai untuk hasil tulisan yang dibuat oleh siswa. Pemberian nilai pada hasil tulisan siswa disesuaikan dengan kriteria penilaian yang telah ditetapkan. Nilai siswa kelas VII SMP Negeri 1 Labuhan Deli dalam menulis teks deskripsi dapat dilihat pada tabel berikut ini.

Hasil analisis teks deskripsi berdasarkan struktur (a) Identifikasi adalah penentu identitas seseorang, benda, dan sebagainya. Analisis yang dilakukan peneliti terhadap kemampuan menulis teks deskripsi siswa dari segi struktur sudah dapat dikatakan baik berdasarkan rubric penilaian strukstur deskripsi, siawa mampu mengidentifikasi benda-benda yang terdapat di dalam gambar yang diberikan guru untuk diamati oleh siswa. (b) Klasifikasi adalah penyusunan bersistem dalam kelompok menurut kaidah atau standar yang telah ditetapkan. (c) Deskripsi bagian adlah bagian yang berisi tentang gambaran-gambaran bagian dalam teks deskripsi. siswa mampu menggunakan struktur dengan tepat, menjelaskan aspek-aspek objek dan penjelasan objek yang terdapat di dalam gambar dengan rinci.

Hasil analisis teks deskripsi berdasarkan ciri kebahasaan (a) Banyak menggunakan kata benda sesuai dengan topik sebagai objek utama pemaparannya. 
Dalam teks siswa penggunaan kata benda sudah dapat dikatakan baik. (b) Banyak menggunakan frasa yang mengandung kata benda yang bersifat non predikatif misalnya gunung tinggi. Dalam teks siswa penggunaan frasa kata benda sudah dapat dikatakan baik. Siswa sudah mampu menggunakan banyak kata benda yang bersifat non predikatif di dalam penulisan teks deskripsi. (c) Banyak menggunakan kata sifat yang bersifat menggambarkan, seperti satu siswa rajin. Dalam teks siswa penggunaan kata sifat sudah dapat dikatakan baik. Siswa sudah mampu menggunakan banyak kata sifat yang bersifat menggambarkan sifat dari objek yang dilihat di dalam teks nya. (d) Banyak menggunakan kata kerja transitif untuk memberikan informasi subjek. Dalam teks siswa penggunaan kata kerja transitif sudah dapat dikatakan baik. Siswa sudah mampu menggunakan banyak kata kerja transitif didalam teksnya. (e) Banyak menggunakan kata kerja (perasaan, pendapat) dengan tujuan mengungkapkan pandangan pribadi penulis tentang subjek. Dalam teks siswa penggunaan kata kerja (perasaan, pendapat) belum dapat dikatakan baik. Hal ini dikarenakan tidak ada ditemukan penggunaan kata kerja (perasaan, pendapat) di dalam teks deskripsi yang dibuat siswa. (f) Banyak menggunakan kata keterangan untuk memberikan informasi. Dalam teks siswa penggunaan kata keterangan sudah dapat dikatakan baik. Siswa sudah mampu menggunakan banyak kata keterangan di dalam teksnya. (g) Banyak menggunakan bahasa kiasan yang berupa perumpamaan atau metafora, seperti kulitnya lembut seperti benang sutra. Dalam teks siswa penggunaan bahasa kiasan sudah dapat dikatakan baik. Siswa sudah mampu menggunakan banyak bahasa kiasan di dalam teksnya.

\section{PEMBAHASAN HASIL PENELITIAN}

\section{Pembahasan Penelitian Penerapan Langkah-Langkah Model} Kontekstual dalam Pembelajaran Menulis Teks Deskripsi Siswa

Aqip ( 2013: 1 ) menyatakan model kontekstual merupakan konsep belajar yang membantu guru mengaikan antara materi yang diajarkan dengan situasi dunia nyata siswa dan mendorong siswa membuat hubungan antara pengetahuan yang 
dimilikinya dengan penerapannya dalam kehidupan mereka sebagai anggota keluarga dan masyarakat. Berdasarkan lembar observasi penilaian aktivitas guru, guru sudah melakukan persiapan mengajar terlihat dari ketersediaan perangkat pembelajaran, sumber belajar yaitu buku siwa, lembar kerja, dan media pembelajaran berbentuk gambar pemandangan.

Penerapan model yang dilakukan oleh guru, berdasarkan pengamatan yang dilakukan oleh peneliti terhadap kegiatan guru didepan kelas pada proses belajar mengajar teks deskripsi, penerapan model kontekstual yang dilakukan guru sudah terdapat didalam katagori baik walaupun guru tidak melaksanakan semua indikator yang terdapat didalam langkah-langkah model kontekstual hal ini ini dapat dilihat berdasarkan lembar observasi penerapan model kontekstual dalam menulis teks deskripsi yang sudah divalidasi dan di dalamnya terdapat tujuh belas indikator yang seharusnya dilaksanakan oleh guru pada saat proses pembelajaran teks deskripsi berlangsung tetapi dalam proses yang dilakukan oleh guru, guru hanya melakukan enam belas indikator dengan nilai presentasi $94 \%$ hal ini terjadi karena guru tidak menggunakan waktu secara efektif dan efisien sehingga waktu yang ada tidak cukup untuk melakukan indikator menulis ringkasan secara mandiri yang terdapat didalam langkah refleksi (reflection).

\section{Pembahasan Penelitian Kemampuan Menulis Teks Deskripsi Siswa}

Berdasarkan hasil penelitian, diketahui bahwa kemampuan menulis teks deskripsi oleh siswa kelas VII SMP Negeri 1 Labuhan Deli Tahun Pembelajaran 2017/ 2018 secara keseluruhan skor rata-rata 79,93, dikategorikan baik. Kemampuan menulis teks deskripsi siswa sudah di dalam katagori baik karena guru menggunakan model kontekstual dalam proses belajar mengajar di dalam kelas, dengan menggunakan model kontekstual yang diterapkan guru, siswa bebas mengeluarkan pendapat dan menghubungkan pengetahuan dengan pengalaman yang dimiliki berdasarkan kehidupan nyata yang dialami oleh siswa secara alamiah untuk membuat

teks deskripsi, karena dalam model ini tugas guru adalah membantu siswa untuk 
mencapai tujuan dan mengelolah kelas sebagai sebuah tim yang bekerja sama untuk menemukan yang baru bagi siswa. Sesuatu yang baru dapat dicapai oleh siswa menemukan sendiri bukan dari apa kata guru. Ada dua aspek yang dinilai dalam kemampuan menulis teks deskripsi siswa, yaitu dari aspek struktur dan ciri kebahasaan. Berdasarkan penelitian yang telah dilakukan, dari aspek struktur siswa memperoleh nilai 66,64 berada pada kategori cukup dan dari aspek ciri kebahasaan siswa memperoleh nilai 62,67 berada pada kategori cukup.

\section{PENUTUP}

Berdasarkan hasil penelitian dan pemabahasan yang telah diuraikan, maka dapat diambil kesimpulan sebagai berikut.Penerapan model kontekstual dalam pembelajaran menulis teks deskripsi siswa kelas VII SMP Negeri 1 Labuhan Deli yang dilakukan guru sudah baik meskipun belum dilakukan secara keseluruhan memenuhi tujuh belas langkah bagian dari tujuh penerapan model kontekstual. Hal ini dibuktikan dari guru hanya melakukan enam belas langkah model pembelajran kontekstual dari tujuh belas langkah model kontekstual dengan persentase $94 \%$ yang dicapai.

Berdasarkan analisis kemampuan menulis teks deskripsi siswa kelas VII SMP Negeri 1 Labuhan Deli Tahun Pembelajaran 2017/2018, dapat disimpulkan bahwa kemampuan siswa dalam menulis teks deskripsi berdasarkan struktur dan ciri kebahaaan secara keseluruhan kemampuan menulis siswa sudah dapat dikatakan ke dalam kategori baik dengan nilai rata-rata yang diproleh oleh siswa yaitu 79,93.

\section{DAFTAR PUSTAKA}

Aqip, zainal. 2013. Model-Model Media, dan Strategi Pembelajaran Kontekstual (Inovatif)

Ferlin, dkk. 2012. Perbedaan Ketrampilan Menulis Deskripsi Dengan Menggunakan Pendekatan Kontekstual dan Metode Quantum Learning Siswa. Padang.: universitas negeri padang. 
M.S, Mahsun. 2014. Teks dalam pembelajaran bahasa Indonesia kurikulum 2013. Jakarta: PT RajaGrafindo Persada.

Rahayu, Sri. 2013. Penerapan Model Pembelajaran Kontekstual Dalam Pembelajaran Menulis Pada Siswa Kelas XII SMKN 1 Denpasar. Vol 2. Bali: Universitas Ganesa

Siregar, mawarni rima. 2014. Pengaruh model pembelajaran berbasis masalah terhadap kemampuan menulis teks deskripsi siswa. Medan :Universitas Negeri Medan.

Sugiono, Dr. 2012. Metode Penelitian Pendidikan. Bandung : Alvabeta, cv.

Yamin, Martinis. 2013. Strategi dan Metode Dalam Model Pembelajaran. Jakarta: Referensi Gp Press Group. 